\title{
An attitude study of pregnant women towards anemia
}

\author{
MANSHA MANI TRIPATHI AND ARUN BAHUGUNA
}

Received: 16.12.2015; Revised: 21.03.2016; Accepted: 06.04.2016

See end of the paper for authors' affiliations

MANSHA MANI TRIPATHI

Department of Adult Continuing

Education and Extension, HNB

Garhwal Central University,

Srinagar, GARHWAL

(UTTARAKHAND) INDIA
ABSTRACT : A random sample of 60 (30 urban and 30 rural) pregnant women of 18-45 age group were selected from three rural and urban settlements of Gorakhnath block of District Gorakhpur (U.P.) for this study. From the result it is clear that there is no significant difference in the attitude level of urban and rural pregnant women towards anemia.

KEY WORDS: Attitude, Pregnant women, Anemia, Health, Nutrition

- HOW TO CITE THIS PAPER : Tripathi, Mansha Mani and Bahuguna, Arun (2016). An attitude study of pregnant women towards anemia. Asian J. Home Sci., 11 (1) : 22-28, DOI: 10.15740/HAS/AJHS/11.1/ 22-28. 